\title{
Comparative effects of niridazole on spermatogenesis and reproductive capacity in the mouse, rat and Japanese quail
}

\author{
Pamela Jones, H. Jackson and M. H. S. Whiting* \\ Unit of Reproductive Pharmacology, University of Manchester, Manchester M13 9PT, U.K.
}

\begin{abstract}
Summary. Niridazole is an effective schistosomicidal compound which, at lower dose levels, affects schistosome gonads. Its antifertility and possible mutagenic effects after various courses of oral treatment were compared in mice, rats and Japanese quail (Coturnix coturnix japonica). In all three species the meiotic stage of spermatogenesis was particularly affected. In mice the highest dose rate (five daily doses of $100 \mathrm{mg} / \mathrm{kg}$ ) produced sterility during the 4 th week. Rats were more susceptible, the compound producing prolonged and, in some animals, permanent sterility against which HCG treatment offered no protection. In quail only a brief phase of sterility occurred. Niridazole appears to be non-mutagenic since dominant lethal mutations were not produced in dose-response studies. Minimal changes in testis histology occurred in the mouse, but in rats severe damage persisted even in animals which had recovered their fertility.
\end{abstract}

\section{Introduction}

Niridazole (Ambilhar: Ciba Laboratories, Basel, Switzerland), a nitrothiazole derivative, was introduced as a schistosomicidal drug for the treatment of bilharzia. Schistosome gonads are affected, low doses inhibiting spermatogenesis, whilst higher doses have a destructive effect upon the cell content of the testes (Striebel \& Kradolfer, 1966; Striebel, 1969). Earlier reports indicated that reversible inhibition of spermatogenesis was induced in various species, including rats and mice, following oral administration of the compound (Lambert et al., 1965). More recent studies have illustrated the selective nature of the antifertility action of niridazole in the mouse and greater susceptibility of the male rat, in which the compound can produce prolonged and perhaps permanent sterility (Jackson, 1973).

From a survey in male mice for potential mutagenicity among a wide range of chemicals (Epstein et al., 1972), niridazole was reported to cause significant reduction in the number of total implantations, which was considered probably due to aspermia, but no significant increase in early fetal deaths. Using a single high dose of the compound, a more recent investigation concluded that failure to fertilize was the cause of the reduced implantation numbers (Joshi et al., 1973). This was confirmed in a further study concerned with assessment of dominant lethal mutations following a series of short courses of niridazole treatment, also to male mice (Jackson et al., 1974).

The present work describes a more extensive comparative study of antifertility and possible mutagenic effects following various courses of niridazole treatment to mice, rats and Japanese quail (Coturnix coturnix japonica).

\section{Materials and Methods}

Pure niridazole was administered in fine suspension in arachis oil. Short courses of oral treatment (five consecutive daily doses each of $100,75,60,50$ or $35 \mathrm{mg} / \mathrm{kg}$ ) were administered to groups of male mice. Male rats were given daily oral doses of 100,50 or $25 \mathrm{mg} / \mathrm{kg}$ over periods ranging from 5 to 10 days, whilst quail received five daily oral doses of 100 or $50 \mathrm{mg}$ of the drug $/ \mathrm{kg}$.

\footnotetext{
* Present address: Teesside Polytechnic, Middlesbrough, Teesside, U.K.
} 
The possible protective effect of gonadotrophin on the antifertility effect of niridazole in the rat was also investigated. Five males were treated subcutaneously with 100 i.u. HCG (Pregnyl: Organon)/ day for 9 days and the first of five consecutive oral daily doses of $50 \mathrm{mg}$ niridazole $/ \mathrm{kg}$ on Day 4 of the gonadotrophin treatment; other males received niridazole $(5 \times 50 \mathrm{mg} / \mathrm{kg})$ or $\mathrm{HCG}(9 \times 100 \mathrm{i} . \mathrm{u}$. $)$ only.

Fertility data in mice and rats were obtained by consecutive weekly matings of treated males (Bock \& Jackson, 1957), and in quail by the test described by Jones et al. (1972). Additional information was obtained by examination of ova from female mice and rats after weekly mating with treated males: the mice ova were recovered from oviducts or uterine horns 2 or 4 days respectively after insemination, and those of rats were collected by flushing the uteri 5 days after insemination. Concurrent assessments were also made of the numbers of viable and non-viable implantations in rat and mouse at 14 days of gestation.

Additional males of all three species were killed at selected intervals after treatment and a smear made from the ductus deferens to examine the sperm content and motility. Testes and epididymides were removed, weighed and fixed in Bouin's fluid for histological observation.

\section{Results}

\section{Fertility experiments}

In all three species the meiotic stage of the spermatogenic process was particularly susceptible to the action of the compound. In the mouse at the highest dose level $(100 \mathrm{mg} / \mathrm{kg})$ a progressive decline in fertility occurred from the first week of mating, with sterility in all males during the 4th week from the first dose (Table 1). In the rat, however, its effect was more sustained and involved most pre-meiotic cells including spermatogonia, with the induction of permanent sterility in some animals. After five oral doses of $100 \mathrm{mg} / \mathrm{kg}$, all rats were sterile by Week 5 with fertility gradually returning in three males by Week 13 . Following ten consecutive doses $(50 \mathrm{mg} / \mathrm{kg})$, sterility occurred from Weeks 5 to 14; one animal was fertile in Week 15 and another two by Week 22 (Table 1).

In quail, the maximum tolerated dose of niridazole $(5 \times 100 \mathrm{mg} / \mathrm{kg})$ produced a decline in the percentage of fertile eggs during 12 days from the first dose, followed by a short but well-marked sterile phase lasting 7 days, with a gradual return to control fertility levels thereafter (Text-fig. 1). At a dose of $5 \times 50 \mathrm{mg} / \mathrm{kg}$ eggs were non-fertile for a shorter period between Days 15 to 18 inclusive.

\section{Recovery of ova}

There was a progressive increase in the number of unfertilized eggs in those recovered from mice at 2 and 4 days after mating with males given the highest dose of niridazole $(5 \times 100 \mathrm{mg} / \mathrm{kg})$ reaching $100 \%$ in Week 4 from the first dose (Table 2). A gradual increase in the number of fertilized ova during Weeks 5 and 6 indicated recovery of fertility in treated males. At lower dose levels (75, 50 and $35 \mathrm{mg} / \mathrm{kg}$ ), there was a progressive diminution in response, although even at the lowest level (35 $\mathrm{mg} / \mathrm{kg}$ ) only about $50 \%$ of ova were fertilized in Week 4 (Table 2 ).

In male rats after an oral dose rate of $5 \times 50 \mathrm{mg} / \mathrm{kg}$, all ova recovered from inseminated females were unfertilized during Weeks 4 and 5 from the first dose in animals treated with niridazole or niridazole $+\mathrm{HCG}$, whilst those from the group receiving $\mathrm{HCG}$ alone were fertilized throughout the experimental period. When another group of rats was treated orally with seven doses of $50 \mathrm{mg}$ niridazole $/ \mathrm{kg}$, the unfertilized eggs were recovered during Weeks 4-6 inclusive. At half this dose $(7 \times 25 \mathrm{mg} / \mathrm{kg})$ there was no effect upon the weekly recovery of fertile ova compared with the controls.

\section{Dominant lethal assay}

The number of viable implantations present in female mice at 14 days of gestation followed a similar pattern to that shown in the fertility and egg recovery experiments. Sterility was evident in all males during the 4 th week after the highest dose $(5 \times 100 \mathrm{mg} / \mathrm{kg})$. At the lower dose levels $(75,60$, 


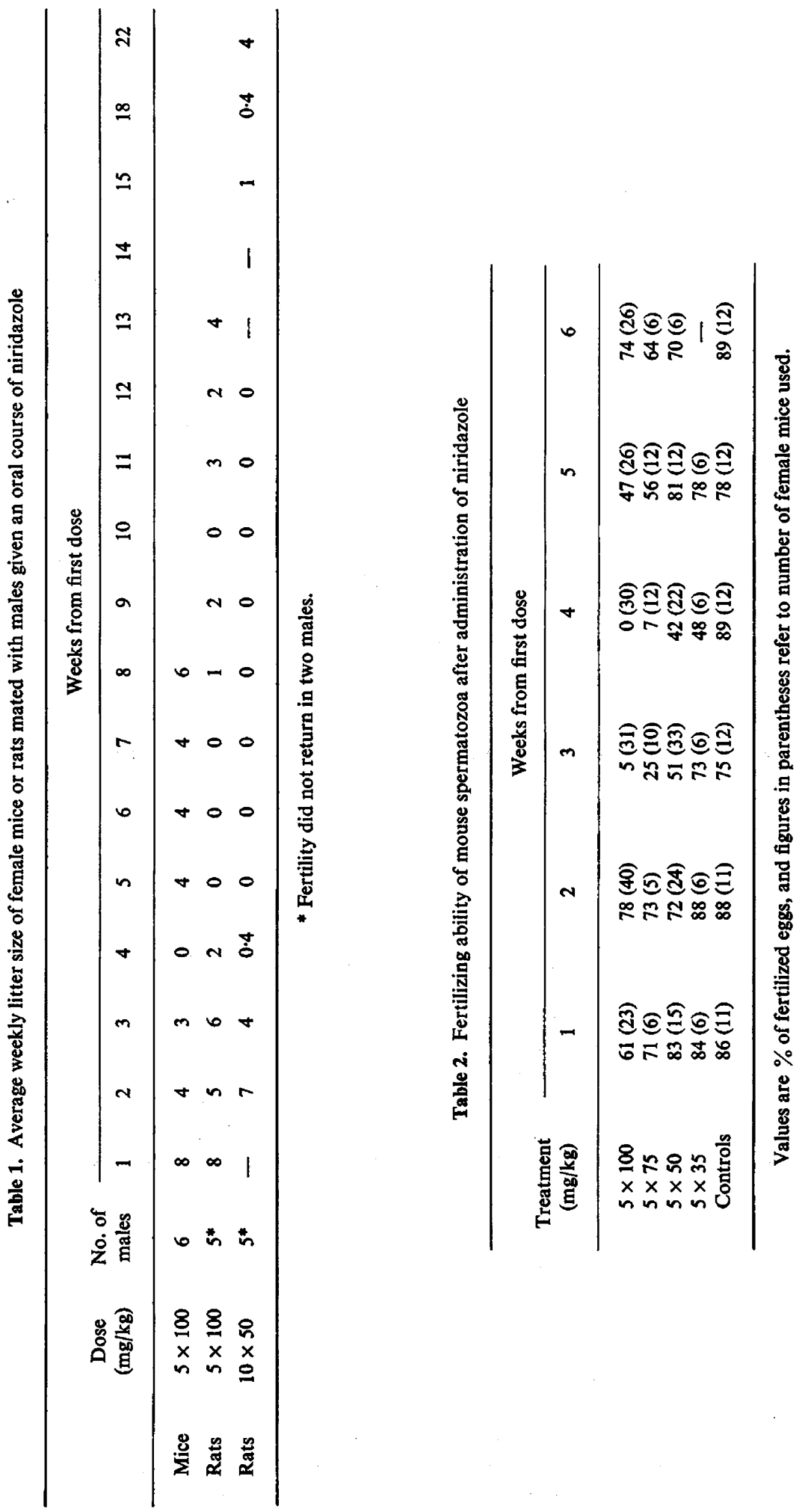




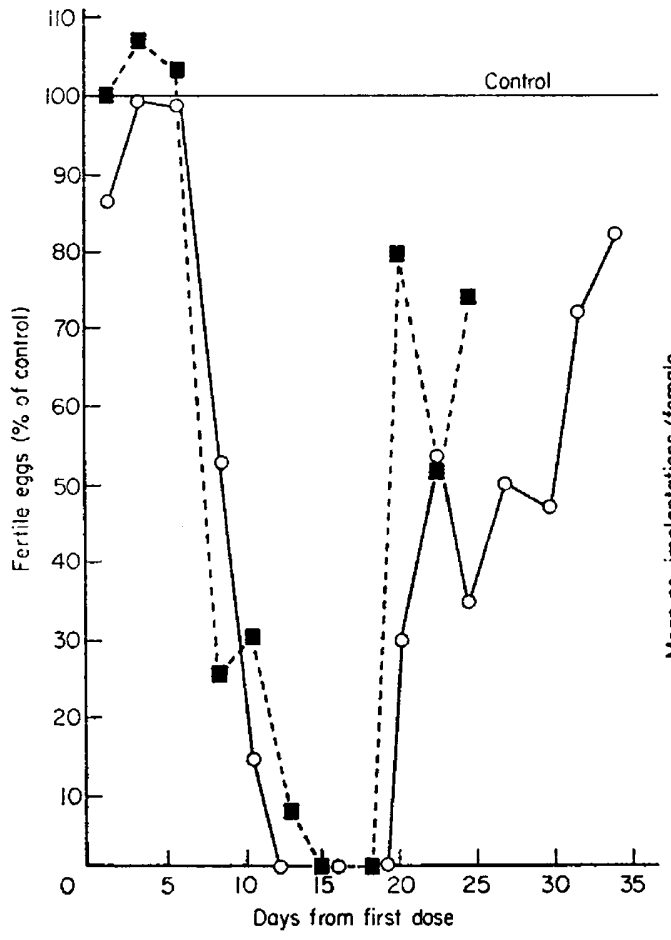

Text-fig. 1

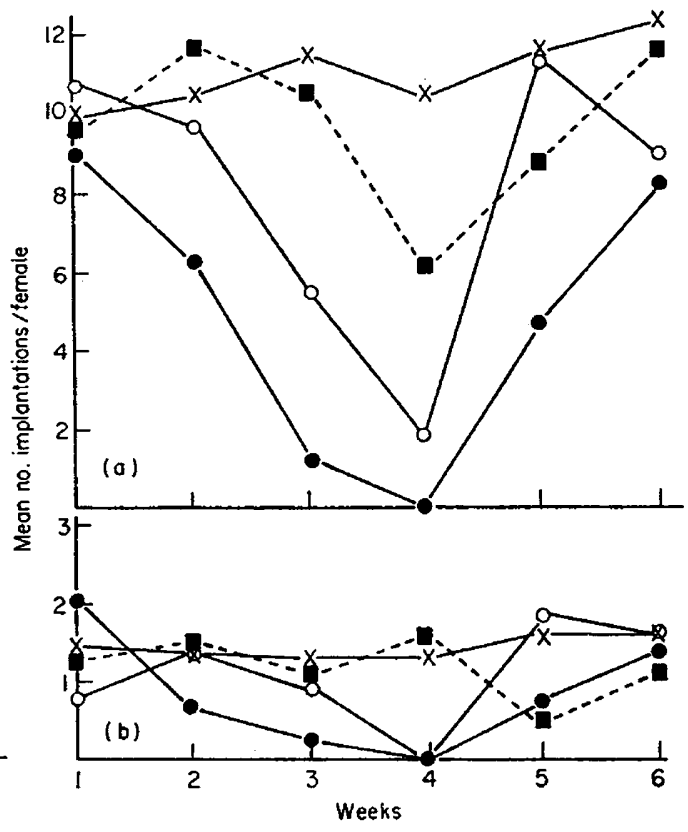

Text-fig. 2

Text-fig. 1. Temporary sterilizing effect of oral niridazole in Japanese quail. $0,5 \times 100 \mathrm{mg} / \mathrm{kg} ; \mathbf{\square}, 5 \times 50$ $\mathrm{mg} / \mathbf{k g}$.

Text-fig. 2. The effect of graded oral doses of niridazole (five daily doses at each level) on reproductive capacity of male mice by (a) weekly assessment of the viable implantations at 14 days of gestation, and (b) assessment of dominant lethal mutations in each of the experiments. At no time was their level significantly higher than the controls. For details and statistical analysis refer to Table 3 . $\times$, Controls; $\bullet, 100 \mathrm{mg} / \mathrm{kg} ; 0,60 \mathrm{mg} / \mathrm{kg} ; \square, 35 \mathrm{mg} / \mathrm{kg}$.

50 and $35 \mathrm{mg} / \mathrm{kg}$ ) there was a graded decrease in response (Table 3 and Text-fig. 2). The incidence of non-viable implantations from the various niridazole treatments was not significantly higher than that in the controls over the whole of the 6-week period of mating (Table 3).

No implantations were found during Weeks 4,5 and 6 in rats mated with niridazole-treated males $(7 \times 50 \mathrm{mg} / \mathrm{kg})$. An increase in the number of viable 14-day fetuses during Weeks 7 to 9 indicated returning fertility in $4 / 10$ males, with another two males recovering by Week 12 (Table 4). At $7 \times 25$ $\mathrm{mg} / \mathrm{kg}$ niridazole had no effect on the weekly implantation rate during Weeks 4-8 from the first dose, and there was no increase in the number of non-viable implantations over that in controls (Table 4).

\section{EXPLANATION OF PLATE 1}

Fig. 1. Mouse testis. $5 \times 100 \mathrm{mg} / \mathrm{kg} ; 2$ weeks from first dose; most tubules show loss of spermatozoa and spermatids; occasional giant cells present. $\times 75$.

Fig. 2. Rat testis. $7 \times 50 \mathrm{mg} / \mathrm{kg} ; 1$ week after first dose; sloughing of spermatids and secondary spermatocytes into lumen of tubules. Conspicuous giant cell formation. $\times 75$.

Fig. 3. Rat testis. $10 \times 50 \mathrm{mg} / \mathrm{kg} ; 24$ weeks from first dose; complete recovery in some tubules; little or no recovery in others. From one of three animals with restored fertility. $\times 75$.

Fig. 4. Rat testis. $10 \times 50 \mathrm{mg} / \mathrm{kg} ; 24$ weeks after first dose; no spermatogenesis; tubules completely depopulated; intercellular stroma increased. From one of two sterile animals. $\times 75$. 
PLATE 1

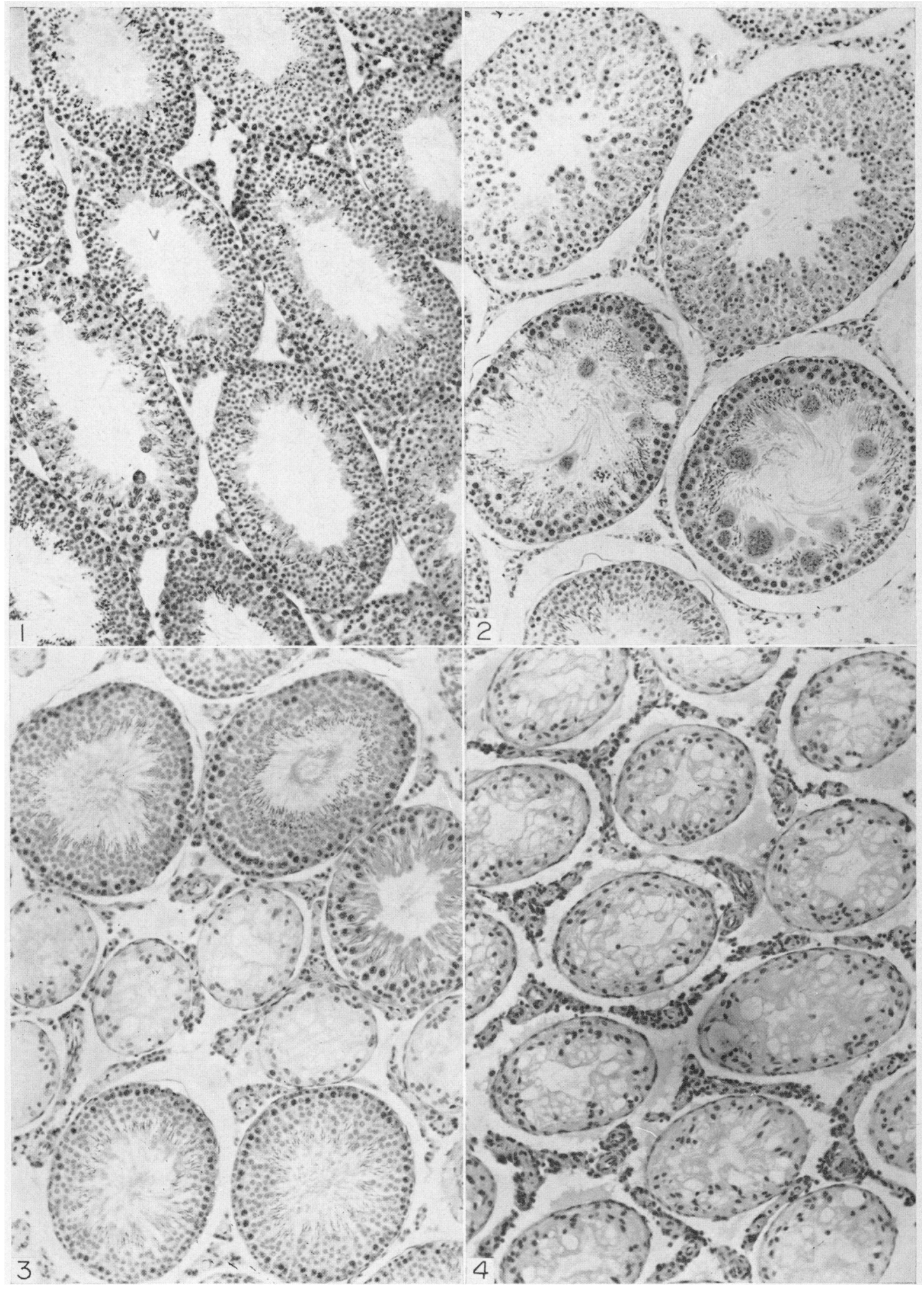

(Facing p. 220) 


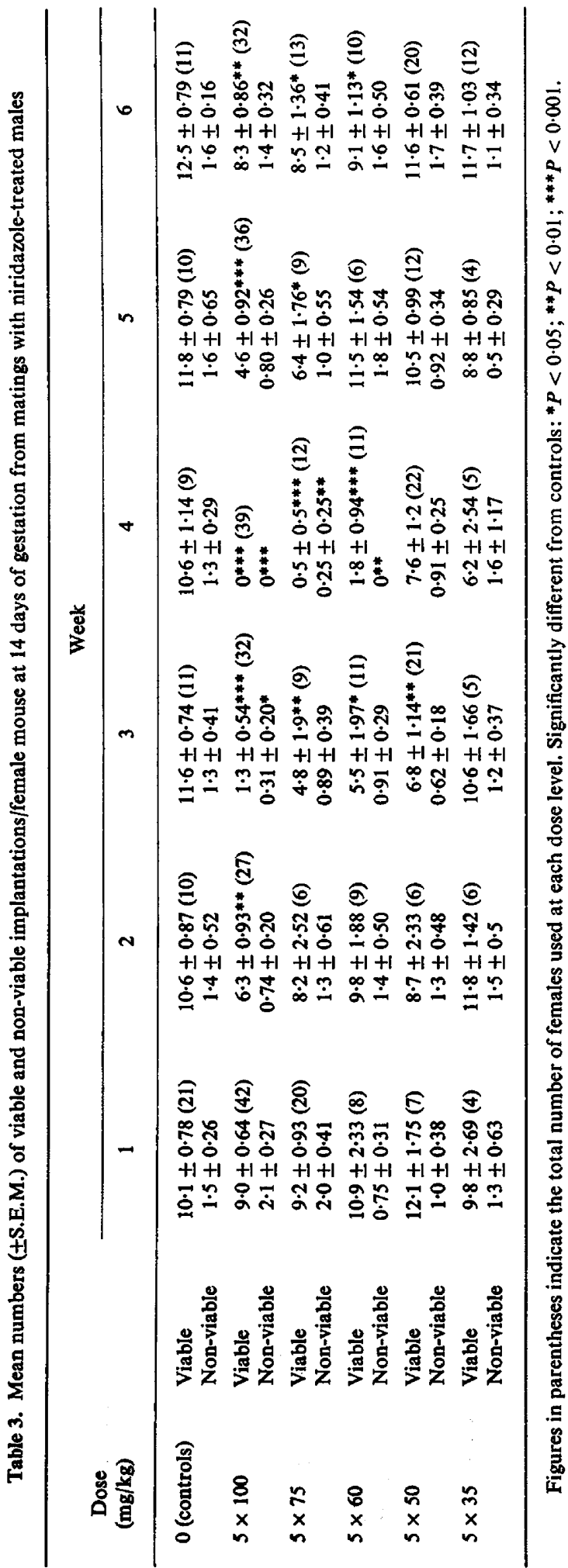




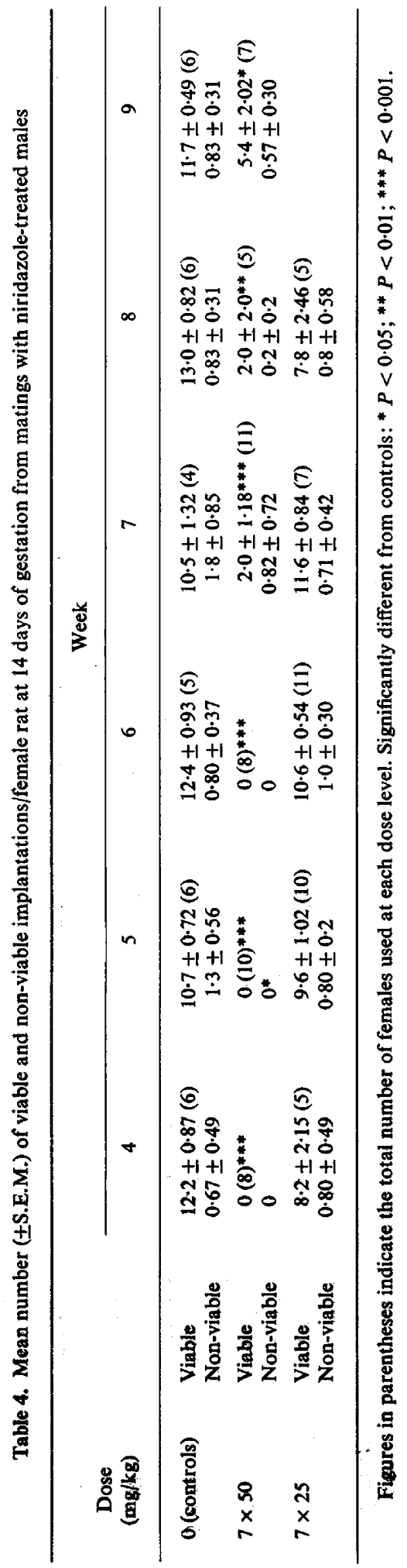




\section{Histological observations}

Testis histology and examination of fluid expressed from the ductus deferens of mice during Weeks $1-6$ after niridazole treatment $(5 \times 100 \mathrm{mg} / \mathrm{kg})$ indicated minimal morphological effects upon spermatogenesis. After 1 week testis histology appeared normal, while at 2, 3 and 4 weeks a minority of tubules showed some degree of disorganization including loss of spermatids and pre-meiotic cells with the formation of giant cells (Pl. 1, Fig. 1). Numerous spermatozoa were present at all times in smears from the ductus deferens but were non-motile during the 4th week from the first dose. Testis histology appeared normal after 5 weeks, except for a few tubules which were still depleted.

In the rat, the testis was considerably affected at all dose levels. After courses of $5 \times 100$ or $10 \times 50$ $\mathrm{mg} / \mathrm{kg}$, only $3 / 5$ males from each group recovered their fertility and, at autopsy of these 6 months after treatment, about $50 \%$ of the tubules were aspermatogenic or showed a disorganized epithelium (Pl. 1, Fig. 3). Motile spermatozoa were recovered from the ductus deferens of these animals. In the remaining two sterile male rats from each dose group the testis tubules were completely depopulated (Pl. 1, Fig. 4). Testis weight was reduced in all animals.

After a shorter course of treatment $(7 \times 50 \mathrm{mg} / \mathrm{kg})$, six males recovered fertility 9-12 weeks later, but the other four appeared to be permanently sterilized. Even in the former, considerable histological damage remained. Giant cells were frequently observed in animals killed during the first few weeks after treatment (Pl. 1, Fig. 2).

At the lowest dose level $(7 \times 25 \mathrm{mg} / \mathrm{kg})$ there was no antifertility effect but the testis still showed damage after 8 weeks; some tubules were empty, others showed a disorganized and deficient spermatogenic epithelium.

Quail testis 1 week after the first dose of niridazole $(5 \times 100 \mathrm{mg} / \mathrm{kg})$ showed disorganization of the spermatogenic epithelium. Sperm clusters were absent, many giant cells were seen, and considerable sloughing of spermatids and spermatocytes occurred. Few spermatozoa were found in the epididymis and those in smears from the ductus deferens were mainly non-motile. By Week 2 repopulation of the peripheral layers had occurred and a few clusters of spermatozoa were seen but none was present in the epididymis or ductus deferens; many tubules were still not fully populated by Week 3 . The histological effects were less noticeable at the lower dose used and the appearance became normal by Week 3 .

\section{Discussion}

Niridazole is currently one of the main drugs used in the treatment of schistosomiasis and it is somewhat surprising that its effects on reproductive cells in species other than the schistosome have received little attention. In an earlier report we commented on the more drastic effects of the compound in the male rat, compared with the mouse (Jackson, 1973). The present results substantiate and amplify the earlier data.

At lower doses than the schistosomicidal level of niridazole in the mouse host, temporary involution of the gonads of both male and female worms occur, the ovary being more sensitive than the testis (Striebel, 1969). In the male mouse, the maximum course of treatment used caused sterility in the 4th week from the first dose, but there was a progressive decline in fertility from the commencement of treatment although recovery had occurred by the 6th week. No evidence of inhibition of sexual activity or effects on the accessory structures was seen so that a direct action on the seminiferous epithelium appears likely, the cells in the meiotic stage of the process being particularly susceptible. The onset of sterility in the mouse was not associated with aspermia since spermatozoa were recovered each week from the ductus deferens although those in Week 4 were non-motile. This is consistent with the observed minimal change in testis histology, so that inhibition of the spermatogenic process appears not to be the only factor involved in the antifertility effect in this species. Thus, the mode of action in the mouse also seems to involve the production of incompetent spermatozoa and resembles the functional type of sterility commonly encountered with certain alkylating chemicals (Jackson, 1970). 
In the rat, sterility commenced 4 weeks from treatment and this appeared permanent in a considerable proportion of animals (Table 1). The seminiferous epithelium was obviously more susceptible than that in the mouse and lower dose levels of treatment caused severe histological damage, persisting even in animals which had recovered their fertility. Treatment with HCG offered no protection against the effect of niridazole, indicating that hormonal mechanisms are not affected by this compound.

Male Japanese quail were less susceptible in so far as only a brief period of sterility ensued, but this is related to the shorter duration of spermatogenesis in this species (Jones \& Jackson, 1972). Perhaps metabolic conversion to a more active compound is involved in species susceptible to the drug. The nitro-group appears to be essential for the schistosomicidal action of niridazole (Robinson et al., 1973), although structure/activity relationships regarding the antifertility effects in rodents are not yet available. The possibility that metabolic reduction occurs with the formation and involvement of hydroxylamine derivatives in the schistosomicidal action has to be considered, but so far no direct evidence of such a transformation has been obtained.

Interference with the spermatogenic process by a considerable variety of alkylating chemicals, particularly those producing a functional type of sterility, is frequently associated with mutagenicity as shown by the induction of dominant lethal mutations (Bateman \& Jackson, 1974; Epstein et al., 1972). With niridazole, our dose-response study in both mice and rats has led to the important conclusion that its action does not involve the concurrent production of dominant lethal mutations, the induction of which is currently regarded as perhaps the most reliable guide to mutagenicity. This finding is of considerable importance in relation to the widespread clinical usage of this compound.

The epididymal sterilizing action of $\alpha$-chlorohydrin, a potential alkylating chemical, also does not involve the induction of dominant lethal mutations (Jackson, 1970; Epstein et al., 1972). These experimental results with niridazole and $\alpha$-chlorohydrin lend encouragement to the search for male antifertility chemicals which could be free from this primary unacceptable hazard.

\section{References}

Bateman, A.J. \& JACkson, H. (1974) Screening for mutagenic hazards of potential chemical contraceptives in the male. In Pharmacological Models in Contraceptive Development, pp. 224-239. WHO Symposium, Geneva, 1973. Eds M. H. Briggs \& E. Diczfalusy. Bogtrykkeriet Forum, Copenhagen.

Bock, M. \& JACKsON, H. (1957) The action of triethylenemelamine on the fertility of male rats. Br. $J$. Pharmac. Chemother. 12, 1-7.

Epstein, S.S., Arnold, E., Andrea, J., Bass, W. \& Bishop, Y. (1972) Detection of chemical mutagens by the dominant lethal assay in the mouse. Toxicol. appl. Pharmac. 23, 288-325.

J ACKSON, H. (1970) Antispermatogenic agents. Br. med. Bull. 26, 79-86.

JACKsON, H. (1973) Comparative effects of some antispermatogenic chemicals. In The Regulation of Mammalian Reproduction, pp. 257-268. Eds S. J. Segal, R. Crozier, P. A. Corfman \& P. G. Condliffe. C. C. Thomas, Springfield, Illinois.

JACkson, H., Jones, P. \& Whiting, M.H. (1974) Assessment of dominant lethal mutations in niridazole-treated male mice. IRCS $\mathrm{Med}$. Sci. 2, 1331 .
JONES, P. \& JACKSON, H. (1972) Estimation of the duration of spermatogenesis in Japanese quail Coturnix coturnix japonica, using antispermatogonial chemicals. J. Reprod. Fert. 31, 319-322.

Jones, P., Kominkova, E. \& JACKson, H. (1972) Effects of antifertility substances on male Japanese quail. $J$. Reprod. Fert. 29, 71-78.

JoshI, S.R., Bishop, Y. \& Epstein, S.S. (1973) Reduced fertility in male mice following treatment with niridazole. Experientia 29, 1253-1255.

LAMbert, C.R., Sinari, V.S.P. \& Tripod, J. (1965) Effect of CIBA $32,644-B A$ on spermatogenesis in laboratory animals. Acta trop. 22, 155-161.

Rorinson, C.H., Spengel, S. \& Bueding, E. (1973) Structure and antischistosomal activity in the nitrofuran series. Requirement for a 5-nitro group in 3-(5-nitro-2-furyl) acrylic acid derivatives. J. med. Chem. 16, 79-80.

Striebel, H.P. (1969) The effects of niridazole in experimental schistosomiasis. Ann. N.Y. Acad. Sci. 160, 491-518.

Striebel, H.P. \& Kradolfer, F. (1966) Mode of action of CIBA 32,644-Ba in experimental schistosomiasis. Acta trop., Suppl., 9, 54-58.

Received 20 March 1975 